\title{
LEVE
}

Landsforeningen for etterlatte ved selvmord

Ved Terese G røm

\section{Landsmøte for LEVE, Stjørdal, 26. mai 2002}

Tiden er inne for å ta ungdommens behov på alvor. Det kom tydelig frem ved årets landsmøte for LEVE under diskusjonen rundt forslaget til Strategisk handlingsplan for LEVE i perioden 2002 - 2005. Planen ble godt mottatt av LEVEs delegater og øurige medlemmer som var til stede.

På landsmøtet i 2001 ble det vedtatt å starte arbeidet med utviklingen av en strategisk handlingsplan for perioden 2002 - 2005. D ette forslaget ble lagt frem til diskusjon og vedtatt ved årets landsmøte. Vi gjengir her i hovedtrekk de viktigste arbeidsområdene i planen.

\section{Organisasjon}

- Fortsette å etablere formelle strukturer i organisasjonen som er uavhengige av enkeltpersoner.

- Styrke sekretariat sentralt. LEVE er i sterk utvikling på flere områder:

- stor pågang fra etterlatte og andre - profilering i media.

- U ngdomsavdeling: $M$ ålsettingen er at LEVE innen planperiodens utløp har en godt organisert ungdomsavdeling med tilbud og aktiviteter. Internett og SM S er kodeord blant unge.

\section{Informasjon og profilering}

- Vurdere å øke omfanget på LEV Enytt i retning av magasin/blad i løpet av planperioden (avhengig av økte ressurser i sekretariatet)

- Elektroniske medier; fortsette utviklingen av hjemmesider på Internett, benytte SM S for kommunikasjon med ungdom.

- Etablere og videreutvikle samarbeid med ulike yrkesgrupper og fagmiljøer som arbeider med forbyggende og kurativt arbeid i forbindelse med selvmord.

\section{Omsorg}

- Bidra til økt offentlig omsorg gjennom et utstrakt samarbeid med kommunale, fylkeskommunale og regionale fagmiljøer og styringssystemer. I dette arbeidet er fylkeslagene viktige aktører.

- U tvikle LEV Es eget omsorgsarbeid gjennom sorgstøtte til etterlatte, og støtte for sorgstøtte til dem som yter likemannsarbeid.

\section{Forskning}

- Et definert mål for LEVE er å "forestå vitenskapelig forskning omkring etterlattes situasjon ved selvmord spesielt og selvmord generelt, ved å stille midler til rådighet/bidra til forskning"

(§ 1.5 - vedtektene).

$\emptyset \mathrm{kt}$ satsing på dette området krever at det:

1) foreligger føringer for fagrådets funksjon

2) planlegges og initieres prosjekter

3) opparbeides kompetanse til å søke prosjekt- og forskningsmidler.

\section{5. Økonomi og finansiering}

- A rbeide mot, i tillegg til prosjektrelaterte statsmidler og medlemsinntekter, å etablere mer varige inntektskilder.

- Det bør nedsettes en "økonomigruppe", som kan gi innspill og idéer til LEVES videre utvikling.

Terese $\mathrm{G}$ røm er informasjonsmedarbeider i LEVE.

\section{Hovedarbeidsområder:}

\section{Omsorg}

- å sikre aktiv hjelp og støtte til familier, pårørende og evt. andre berørte som mister noen av sine nærmeste ved selvmord. Et offentlig oppfølgingstilbud er også viktig.

\section{Informasjon}

- å drive opplysningsvirksomhet og spre informasjon om selvmord og etterlattes situasjon $i$ befolkningen og blant helsepersonell.

\section{Forskning}

- å arbeide aktivt for å skaffe midler til forskningsformål, for å forebygge selvmord og bedre omsorgen for dem som er rammet.

\section{LEVE}

Postboks 27 Smestad, 03090 slo

Telefon/faks.: 22523005

E-post: leve.no@online.no

Internettadresse: www.levenorge.no

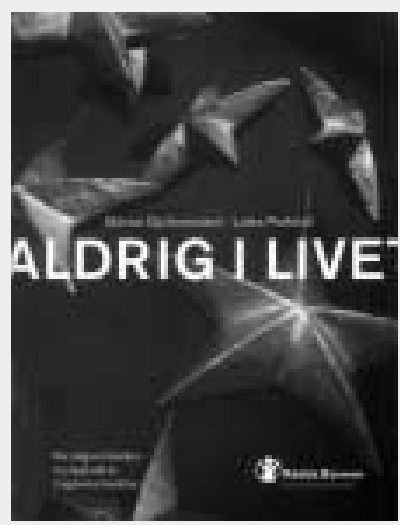

Gyllenswärd, G öran / Polfeldt, Lotta A Idrig i livet: när någon i familjen har tagit sitt liv: ungdomar berättar.

Stockholm: Rädda Barnen, 2001. - $94 \mathrm{~s}$. ISBN 91-89366-72-7.

E-post: info@rb.se / faks: 086989010

Seks tenåringer forteller om hvordan det er å miste foreldre eller søsken i selvmord, og om hvordan det har påvirket dem videre i livet. $\mathrm{Her}$ er både smerte og håp.

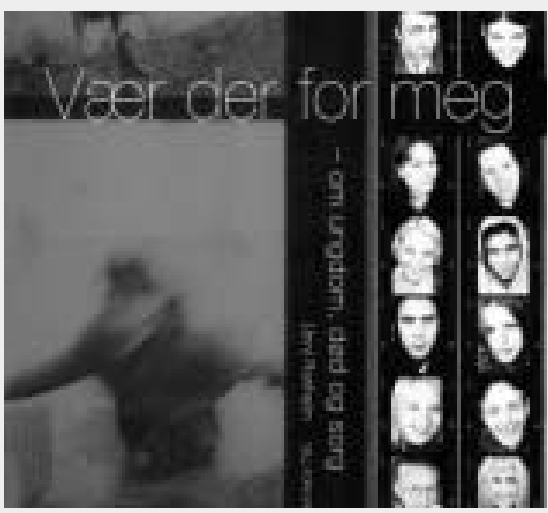

Ranheim, U nni (red.)

$V$ ær der for meg: om ungdom, død og sorg.

Vollen: Tell, 2002. - $107 \mathrm{~s}$

ISBN 82-7522-193-5.

(Kan kjøpes i bokhandel)

Tolv ungdommer formidler hvordan de har opplevd ulike typer dødsfall blant venner eller i familien, og om hvordan de har opplevd og taklet sorgen. $\mathrm{N}$ i fagpersoner uttaler seg om ulike temaer knyttet til sorgreaksjoner hos ungdom. 